Reprod. Nutr. Dévelop., 1987, 27 (4), 781-790.

\title{
Valorization of rapeseed meal. 5. Effects of sinapine and other phenolic compounds on food intake and nutrient utilization in growing rats
}

\author{
M. VERMOREL, R. HOCOUEMILLER $\left({ }^{*}\right)$, J. EVRARD $\left({ }^{* *}\right)$
}

with the technical assistance of Y. ANGLARET, C. LEOTY, Marinett MARTINAUD and R. SOUCHET

Laboratoire d'Etude du Métabolisme Energétique

I.N.R.A., Theix, 63122 Ceyrat, France.

(*) Laboratoire de Pharmacologie, Centre d'Etudes Pharmaceutiques, 92290 Châtenay-Malabry.

(**) CETIOM, Centre Technique Interprofessionnel des Oléagineux Métropolitains, rue Monge, 33660 Pessac.

\begin{abstract}
Summary. Six groups of 10 growing rats each were fed ad libitum for 15 days one of six diets : diet $A$, rapeseed $(3.80 \mathrm{~g}$ of sinapine $/ \mathrm{kg} \mathrm{DM})$; diet $\mathrm{B}$, ethanol/water-extracted rapeseed $(0.48 \mathrm{~g}$ of sinapine) ; diet $\mathrm{C}$, control diet ; diet $\mathrm{G}$, control diet $+3.74 \mathrm{~g}$ of extracted sinapine ; diet $\mathrm{H}$, control diet $+3.72 \mathrm{~g}$ of sinapine + other phenolic compounds ; or diet I, control diet + the hydrolysis products of sinapine and other phenolic compounds.

During the first 8 days, the dry matter intake and live weight gain of the rats were significantly reduced by the intake of sinapine and other phenolic compounds. However, after this adaptation period their performances were similar to those of the control group. Dry matter, energy and nitrogen digestibility and protein utilization were not altered by sinapine intake but were slightly reduced with diets $\mathrm{H}$ and $\mathrm{I}$.
\end{abstract}

\section{Introduction.}

Rapeseed and the meal derived from it contain several toxic compounds which limit their use as protein sources for animal feed (see review by Bell, 1984). The toxic effects of glucosinolates and related compounds have been extensively studied in rats and most farm animals (see reviews by Rundgren, 1983 ; Thomke et al., 1983). Phytic acid forms complexes with macro and trace elements, reducing their availability and thus provoking deficiencies in some cases. Similarly, tannins complex with minerals and some amino acids, reducing the digestibility and biological value of proteins (Vohra, Katzer and Joslyn, 1966 ; Glick and Joslyn, 1970 ; Fenwick and Hoggan, 1976).

Rapeseed also contains phenolic esters of choline (derivatives of cinnamic and benzoic acids), and mainly sinapine ( $85 \%$ ) (Kozlowska, Sabir and Sosulki, 1975 ; 
Larsen et al., 1983). It has long been known (Schwarze, 1949) that this compound is responsible for the bitter taste of rapeseed, which reduces its palatability, and it may cause the disagreeable taste of milk and meat from cows and calves fed rapeseed (Anderson and Anderson, 1982, quoted by Larsen et al., 1983), although there is no sensory evidence of this. The sinapine content of low-glucosinolate rapeseed meals, obtained by plant breeding, is comparable with that of older varieties : 6 to $18 \mathrm{~g} / \mathrm{kg}$ dry matter (Fenwick and Hoggan, 1976; Fenwick and Curtis, 1980).

Sinapine is degraded in the rat gut (Bille et al., 1983) ; in the caeca of poultry it gives rise to trimethylamine (TMA) (Müller, Coleman and Clandinin, 1978). In hens producing brown-shelled eggs, the goitrin, or VTO, derived from the glucosinolates in rapeseed blocks the thyroid, causing and inhibition of TMA oxidase synthesis in liver microsomes (Pearson et al., 1979; Goh, Robblee and Clandinin, 1983). The accumulation of TMA in eggs causes a crabbly/fishy taint (Hobson-Frohock et al., 1973). In contrast, the few results concerning the effects of sinapine on growth are not conclusive, e.g. extracted sinapine does not appear to have any effect on the weight gain and feed efficiency of chicks and rats (Clandinin, 1961 ; Austin and Wolff, 1968). However, Josefsson and Uppström (1976) found that it reduced intake and growth rate in rats without decreasing the nutritive value of feeds. Furthermore, there is no data concerning the toxicity of other phenolic compounds. The aim of the present study was to determine the effect of sinapine and other phenolic compounds extracted from rapeseed on rat growth and the protein value of feeds.

\section{Material and methods.}

Feeds and extraction of phenolic compounds (fig. 1).

Feed $A$ was a double zero rapeseed meal with a very low glucosinolate content $(0.45 \mathrm{~g}$ of ITC $/ \mathrm{kg}$ DM and only traces of VTO). Oil was extracted with hexane at $105^{\circ} \mathrm{C}$. After desolventization, the rapeseed meal was cooked at $105^{\circ} \mathrm{C}$. It contained $392 \mathrm{~g}$ of crude protein and $11.5 \mathrm{~g}$ of sinapine $/ \mathrm{kg}$ DM. The sinapine content was determined by the method of Legueult, Hocquemiller and Cave (1981), i.e. sinapine thiocyanate, formed from potassium thiocyanate, was measured by ultraviolet spectrophotometry $(330 \mathrm{~nm})$.

Feed $B$ included the residue from meal $A$ after aqueous alcohol extraction. It contained $440 \mathrm{~g}$ of crude protein and only $1.6 \mathrm{~g}$ of sinapine $/ \mathrm{kg} \mathrm{DM}$. The sugars, alphagalactosides, sinapine, sinapic acids and flavonol glucoside esters had been extracted by the aqueous alcohol solution ( $80 \%$ ethanol) (Tantawy, Robin and Thollier, 1983).

Extract $G$ was obtained after evaporation of ethanol in the aqueous alcohol extract, treatment of the aqueous extract with petrol ether and then with ethylacetate to eliminate weakly charged compounds such as aglycons, and finally, extraction of phenolic compounds with butanol. This extract represented $10 \mathrm{~g}$ of dry product $/ \mathrm{kg}$ of meal and contained $31.2 \%$ of sinapine along with other phenolic compounds. Extract $H$ was the freeze-dried residue of the aqueous extract, representing 


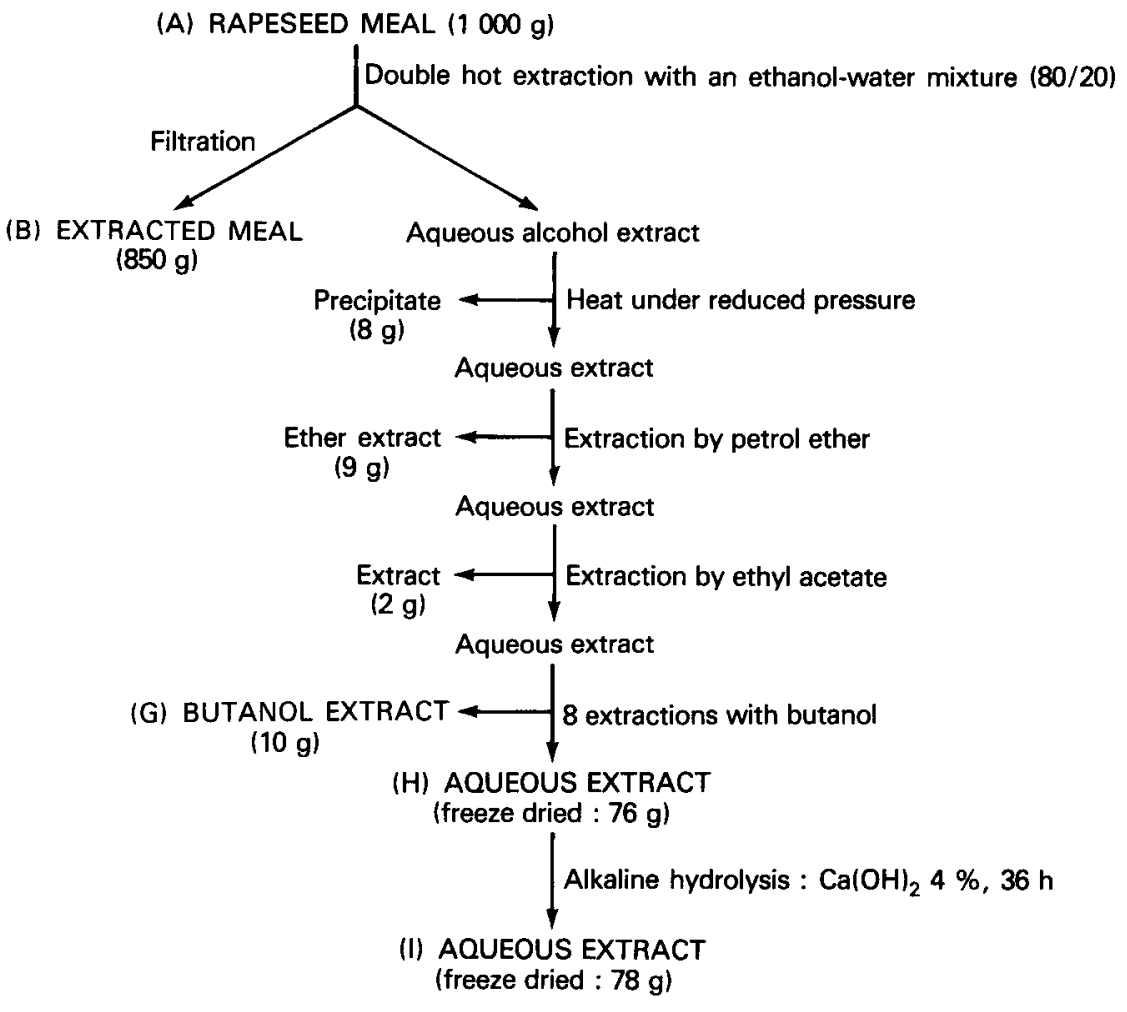

FIG. 1. - Methods of preparation of phenolic extracts.

$76 \mathrm{~g} / \mathrm{kg}$ of rapeseed meal and containing only $4.9 \%$ of sinapine and other phenolic compounds.

Extract / was obtained after alkaline hydrolysis of extract $\mathrm{H}$ to destroy the sinapine. Extract I $(78 \mathrm{~g} / \mathrm{kg}$ of meal) contained no sinapine but its degradation products (especially sinapic acid and choline) and other phenolic compounds.

\section{Diets studied (table 1).}

Diets $A$ and $B$ : the whole (A) rapeseed meal or its extract (B) was the sole source of protein in the diet, supplemented by $0.50 \mathrm{~g}$ of L-lysine $/ \mathrm{kg} \mathrm{DM}$. These diets contained 3.80 and $0.48 \mathrm{~g}$ of sinapine/ $\mathrm{kg}$ DM, respectively.

Diet $C$ (control) : a semi-synthetic diet based on wheat starch and herring meal supplemented with methionine.

Diet $G$ : the control diet to which was added $12 \mathrm{~g}$ of extract $\mathrm{G} / \mathrm{kg} \mathrm{DM}$ so that the sinapine content was similar to that of $\operatorname{diet} A$.

Diet $H$ : the control diet with $76 \mathrm{~g}$ of $\mathrm{H}$ extract $/ \mathrm{kg} \mathrm{DM}$. Its sinapine content was also close to that of diet $A$.

Diet 1: the control diet $+72 \mathrm{~g}$ of extract $\mathrm{l} / \mathrm{kg} \mathrm{DM}$. This diet contained no sinapine but the proportions of its hydrolysis products corresponded to the sinapine contents of diets $A, G$ and $H$. 
TABLE 1

Composition of the diet $(\mathrm{g} / \mathrm{kg} D M)$

\begin{tabular}{|c|c|c|c|c|c|c|}
\hline Diet & A & B & C & $\mathbf{G}$ & $\mathrm{H}$ & I \\
\hline Rapeseed cake (A) & 330 & - & - & - & - & - \\
\hline Extracted rapeseed cake (B) & - & 297 & - & - & - & - \\
\hline Herring meal & - & - & 150 & 150 & 150 & 150 \\
\hline Methionine & - & - & 2.5 & 2.5 & 2.5 & 2.5 \\
\hline L. lysine & 0.50 & 0.50 & - & - & - & - \\
\hline G. extract & - & - & - & 12 & - & - \\
\hline H. extract & - & - & - & - & 76 & - \\
\hline 1. extract & - & - & - & - & - & 72 \\
\hline Wheat starch & 591.5 & 624.5 & 769.5 & 757.5 & 693.5 & 697.5 \\
\hline Minerals & 40 & 40 & 40 & 40 & 40 & 40 \\
\hline Vitamins + starch & 18 & 18 & 18 & 18 & 18 & 18 \\
\hline Maize oil + vitamins & 20 & 20 & 20 & 20 & 20 & 20 \\
\hline Sinapine & 3.80 & 0.48 & - & 3.74 & 3.72 & Hydrolysis \\
\hline Other phenolic compounds & + & - & - & + & +++ & products \\
\hline Gross energy (kcal) & 4273 & 4240 & 4254 & 4251 & 4249 & 4193 \\
\hline Crude protein & 129 & 132 & 122 & 127 & 132 & 131 \\
\hline
\end{tabular}

All the diets were balanced in essential amino acids and supplemented in minerals, vitamins and essential fatty acids to meet the requirements of growing rats (Vermorel, 1972).

Animals. - Sixty male Sprague-Dawley rats of a mean initial weight of $95 \mathrm{~g}$ were randomly allotted to 6 groups of 10 rats each and reared in individual cages. The protein/energy ratios were similar in diets $A, B$ and $C: 6.38 \pm 0.05 \mathrm{mg}$ of crude protein/kJ metabolizable energy.

Feeding design. - The rats received one of the diets described above during a period of only 15 days due to the small quantities of $\mathrm{G}, \mathrm{H}$ and $\mathrm{I}$ extracts available. Diets $A, B$ and $C$ were fed pure and ad libitum from the first day onwards. Diets $G$, $H$ and $I$ were mixed with the control diet for the first 5 days $(25,25,50,50$ and then $75 \%$ ) in order not to introduce complications which could arise as a result of diet unpalatability. Since the quantity of the products was limited, the number of rats was reduced to 5,8 and 8 from day 8 in groups $G, H$ and I, respectively; the discarded rats were withdrawn randomly.

Measurements. - The rats were weighed at 8 a.m. on days 1, 4, 8, 11 and 15 of the trial. After sacrifice the gut contents were eliminated to permit determination of empty body weight gain (EBWG). The distribution, refusal and intake of each rat were recorded every day.

The faeces and urine from 5 rats in each group were collected separately over a period of 7 days (experimental days 8 to 15) to determine dietary digestibility and nitrogen retention.

The results on intake, growth rate, feed efficiency and diet digestibility were compared by analysis of variance and Student's t-test. 


\section{Results.}

Diet palatability and feed efficiency (table 2).

Effect of extracting sinapine from the rapeseed meal. - The extraction of sinapine and phenolic compounds from the rapeseed resulted in significant increases $(P<0.01)$ in feed intake $(+7 \%)$, live weight gain $(+13 \%)$ and empty body weight gain $(+12 \%)(P<0.05)$. Feed efficiency was improved by $6 \%$ $(0.10<\mathrm{P}<0.05)$ during the whole experimental period, but remained inferior to that obtained with the control diet.

Effect of addition of extracts $G, H$ and $/$. - During the first 8 days, food intake was much lower than with the control diet $(P<0.01)$; means of 20,19 and $16 \%$ were obtained for groups $\mathrm{G}, \mathrm{H}$ and $\mathrm{I}$, respectively, but the differences were reduced over the course of the experiment in spite of the increase in the percentage of extract in the feed. The corresponding daily body weight gains were lower than that of the controls $(P<0.001): 40,39$ and $33 \%$ for groups $G, H$ and I, respectively.

In contrast, after this period of adaptation, food intakes of rats receiving diets $\mathrm{G}, \mathrm{H}$ and $\mathrm{I}$ were very high and similar to that of the control group. Growth rate and feed efficiency were slightly (NS) higher than those of the control group, probably due to compensatory growth.

Digestive and metabolic utilization of proteins (table 3 ).

Effect of extracting sinapine from the rapeseed meal. - The extraction of sinapine and other phenolic compounds from the rapeseed meal had no significant effect on apparent digestibilities of the dry matter, energy and protein of diet B compared with diet $\mathrm{A}$. In addition, it had no effect on the metabolic utilization of protein ; net protein utilization (NPU $=N$ gain $\times 100 / N$ intake) and the coefficient of nitrogen retention ( $C R=N$ gain $\times 100 /$ digestible $N$ ) were very similar for the two diets. Finally, for a given intake of metabolizable energy (ME), the quantities of protein retained were very similar and close to that of the control group.

Effect of addition of extracts. - The incorporation of extract $\mathrm{G}$, rich in sinapine, at a level corresponding to the sinapine content of diet $A$ (whole rapeseed meal), had no significant effect on the dry matter, energy and protein digestibilities of the diet nor on the metabolic utilization of protein. This was demonstrated by the fact that the NPU, CR and quantity of protein fixed for a given ME intake were very similar to those of the control group.

The incorporation of extract $H$ (rich in sinapine and other phenolic compounds), and especially of extract I (containing the hydrolysis products of sinapine and other phenolic compounds), resulted in reductions of 0.8 point in the digestibility of energy and of 1.7 or 2.9 points in protein digestibility $(P<0.05)$. The NPU and CR of nitrogen were also lower than with the control group or group $G$, but the quantities of protein retained for a given ME intake were not significantly different. 


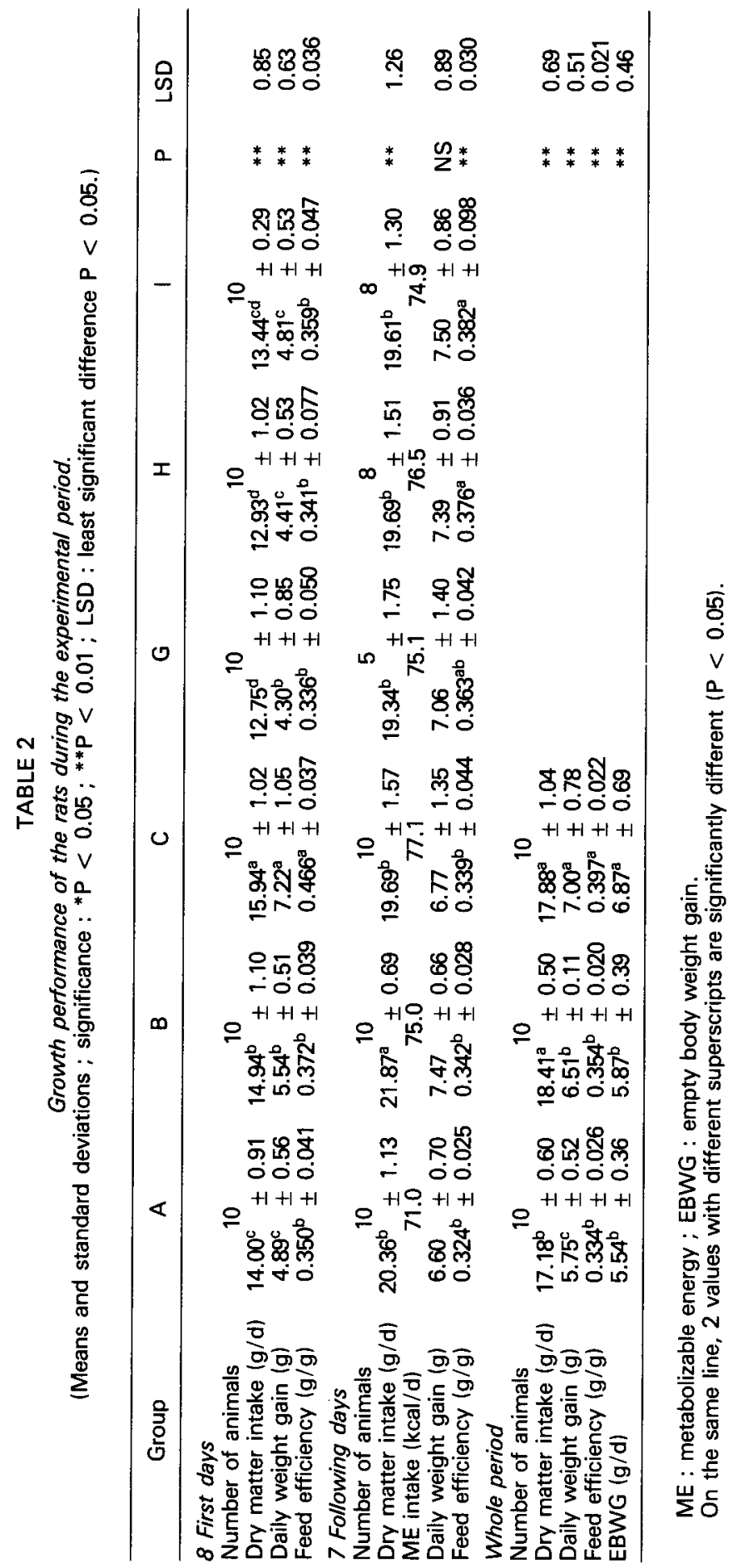




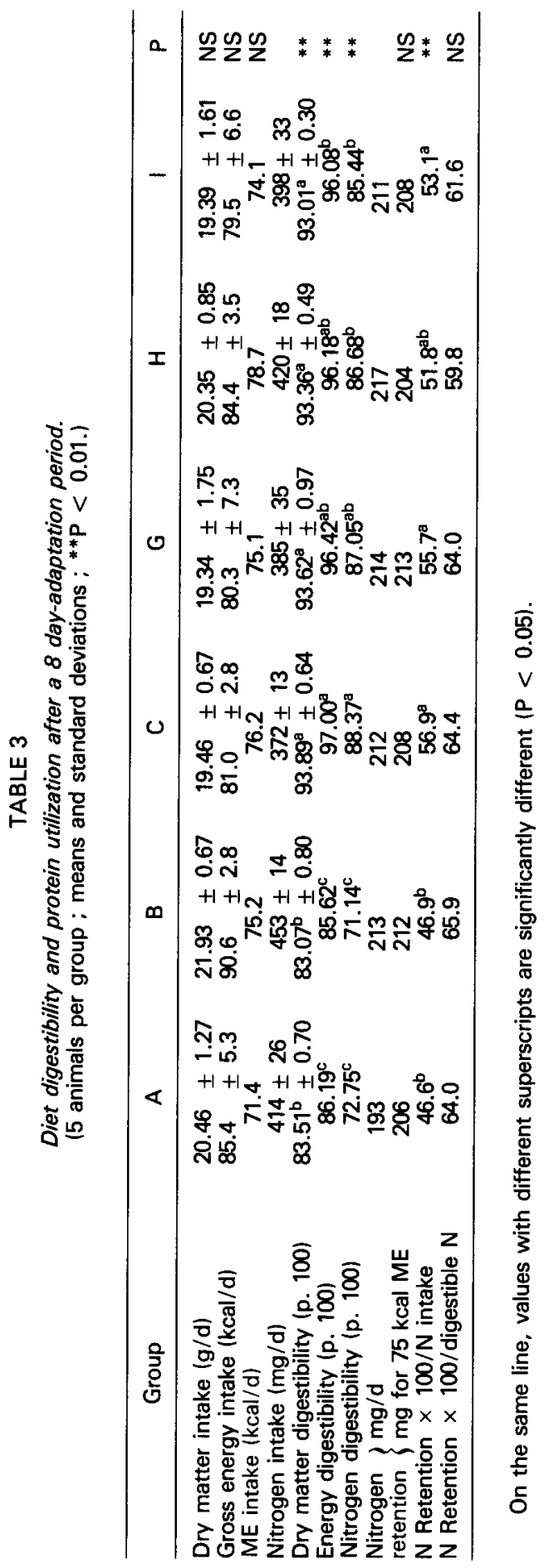


Finally, macroscopic examination did not show any anomaly in the gut, liver or kidneys of rats which had received extracts $G, H$ or I. No pathological investigations were conducted, but it did not appear that sinapine and other phenolic compounds extracted from rapeseed meal had any effect on rats during the 15-day experiment.

\section{Discussion and conclusion.}

After one week of adaptation, the use of rapeseed meal with very low ITC and VTO contents, as a sole source of protein for growing rats, provided a performance level similar to that of the control group; this confirms the results of Vermorel, Fayet and Baudet (1978). In agreement with the results of Josefsson and Uppström (1976), this study indicates that sinapine and other phenolic compounds extracted from rapeseed, and their degradation products, reduced palatability and, thus, rat growth. Extraction of all the phenolic compounds from the rapeseed meal significantly improved intake during the course of the experiment. In contrast, even at a low concentration, the incorporation of sinapin or other phenolic compounds markedly reduced food intake during the first days.

One of the most interesting results of this study is the progressive adaptation of the rats to these compounds when they were added to the control diet. After about one week, animal intake, growth rate and feed efficiency equalled those of the controls - and could be even better due to compensatory growth. These results may be compared with those obtained by Austin and Wolff (1968) on rats, although they gave no details on animal age and performance level.

The results obtained after sinapine was extracted from rapeseed meal, or added to the control diet at an equivalent rate, indicate that sinapine had no depressive effect on digestive and metabolic utilization of protein. These results confirm the conclusions of preceding authors studying the performance of rats or chickens. In contrast, the other phenolic compounds present in extract $\mathrm{H}$ and their hydrolysis products (extract I) appeared to exert a depressive effect on digestive utilization of the dietary components especially protein.

In conclusion, the phenolic compounds in rapeseed meal are partly responsible for the poor palatability of rapeseed diets and reduction in animal performance during the first days. Their effects may be limited by progressive adaptation to the diets. The reduction in feed intake and growth rate of rats fed rapeseed meal, observed after about 10 days, appears to be due to glucosinolates rather than to sinapine (Vermorel, Davicco and Evrard, 1987). Sinapine itself had no depressive effect on the digestive and metabolic utilization of the diet and does not appear to be toxic for growing rats. 
Acknowledgements. - This study was carried out with financial aid from CETIOM within the 1982 CETIOM/INRA program " Recherches sur les Oléagineux ". The authors wish to thank J. P. Robin (INRA, Montpellier) for his suggestions concerning the extraction of the other phenolic compounds.

Résumé. Valorisation du tourteau de colza. 5. Influence de la sinapine et des autres composés phénoliques extraits du colza sur l'appétibilité et la valeur nutritive des régimes chez le rat en croissance.

Six lots de 10 rats en croissance ont reçu ad libitum pendant 15 jours l'un des régimes suivants contenant par $\mathrm{kg}$ de MS, respectivement : $\mathrm{A}$, du tourteau de colza $(3,80 \mathrm{~g}$ de sinapine) ; B, du tourteau de colza extrait par une solution hydro-alcoolique $10,48 \mathrm{~g}$ de sinapine) ; $C$, le régime témoin ; $G$, le régime témoin $+3,74 \mathrm{~g}$ de sinapine extraite $; H$, le régime témoin $+3,72 \mathrm{~g}$ de sinapine et d'autres composés phénoliques ; l, le régime témoin + les produits d'hydrolyse de la sinapine et des autres composés phénoliques.

Au cours des 8 premiers jours, la consommation de matière sèche et le gain de poids vif des rats ont été significativement réduits par l'ingestion de sinapine et des autres composés phénoliques. Cependant, après cette période d'adaptation, leurs performances ont été comparables à celles des animaux témoins. Les digestibilités de la matière sèche et de l'énergie et l'utilisation des matières azotées n'ont pas été modifiées par l'ingestion de sinapine, mais légèrement réduites dans le cas des régimes $\mathrm{H}$ et $\mathrm{I}$.

\section{References}

AUSTIN F. L., WOLFF I. A., 1968. Sinapine and related esters in seed meal of Crambe abyssinica. J. agr. Food Chem., 16, 132-135.

BELL J. M., 1984. Nutrients and toxicants in rapeseed meal : a review. J. anim. Sci., 58, 996-1010.

BILLE N., EGGUM B. O., JACOBSEN I., OLSEN O., SORENSEN H., 1983. The effects of processing on antinutritional constituants and nutritive value of double low rapeseed meal. $Z$. Tierphysiol., Tierernähr., Futtermitte/k., 49, 148-163.

CLANDININ D. R., 1961. Rapeseed oil meal studies. 4. Effect of sinapine, the bitter substance in rapeseed oil meal, on the growth of chickens. Poultry Sci., 40, 484-487.

FENWICK G. R., CURTIS R. F., 1980. Rapeseed meal and its use in poultry diets. A review Anim. Feed Sci. Technol., 5, 255-298.

FENWICK G. R., HOGGAN S. A., 1976. The tannin content of rapeseed meals. Br. Poultr. Sci., 17, 59-62.

GLICK Z., JOSLYN M. A., 1970. Food intake depression and other metabolic effects of tannic acid in the rat. J. Nutr., 100, 509-515.

GOH Y. K., ROBBLEE A. R., CLANDININ D. R., 1983. Influence of glucosinolates and free oxyzolidinethione in a laying diet containing a constant amount of sinapine on the trimethylamine content and fishy odour of eggs from brown-shelled egg layers. Can. J. anim. Sci., 63, 671676.

HOBSON-FROHOCK A., LAND D. G., GRIFFITHS N. M., CURTIS R. F., 1973. Egg taints : association with trimethylamine. Nature, Lond., 243, 304-305.

JOSEFSSON E., UPPSTRÖM B., 1976. Influence of sinapine and p. hydroxybenzylglucosinolate on the nutritional value of rapeseed and white mustard meals. J. Sci. Fd. Agric., 27. 438-442.

KOZLOWSKA H., SABIR M. A., SOSULKI F. W., 1975. Phenolic constituants in rapeseed flour. Can. Inst. Food Sci. Technol. J., 8, 160-163.

LARSEN L. M., OLSEN O., PLOGER A., SORENSEN H., 1983. Phenolic choline esters in rapeseed: possible factors affecting nutritive value and quality of rapeseed meal. Proc. 6th int. Rapeseed Conf., 1577-1582. Paris, 17-18-19 mai 1983. 
LEGUeUlt C., HOCQUeMILleR R., CAVE A., 1981. Dosage de la sinapine. Ann. Pharmac. fr., 39. 557-561.

MÜLLER M. M., COLEMAN R. N., CLANDININ D. R., 1978. Trimethylamine production from sinapine by enteric bacteria from laying hens. Proc. 5th int. Congr., Malmö, 127.

PEARSON A. W., BUTLER E. J., CURTIS R. F., FENWICK G. R., HOBSON-FROHOCK A., LAND D. G., 1979. Effect of rapeseed meal on trimethylamine oxidase activity in the domestic fowl in relation to egg taint. J. Sci. Food Agric., 30, 291-298.

RUNDGREN M., 1983. Low-glucosinolate rapeseed products for pigs. A review. Anim. Feed Sci. Technol., 9, 239-262.

SCHWARZE P., 1949. The bitter substance of rapeseed. Naturwissenschaften, 36, 88-89.

TANTAWY B., ROBIN J. P., THOLLIER M. T., 1983. Caractérisation de deux glycosides acylés du kaemférol dans les extraits éthanoliques du tourteau de colza « $\mathrm{O}$. Thio ». Proc. 6th int. Rapeseed conf., Paris, 17-18-19 mai 1983.

THOMKE S., ELWINGER K., RUNDGREN M., AHLSTROM B., 1983. Rapeseed meal of Swedish low-glucosinolate type fed to boiler chickens, laying hens and growing-finishing pigs. Acta agric. scand., 33, 75-95.

VERMOREL M., 1972. Besoins énergétiques et azotés du Rat en croissance. Expériment. anim., 5 , 249-266.

VERMOREL M., DAVICCO M. J., EVRARD J., 1987. Valorization of rapeseed meal. 3. Effects of diet glucosinolate content on food intake, weight gain, liver weight and plasma thyroid hormono levels in growing rats. Repr. Nutr. Dévelop., 27, 57-66.

VERMOREL M., FAYET J. C., BAUDET J. J., 1978. Valorisation du tourteau de colza. 1. Influence de l'élimination des glucosinolates, du dépelliculage et de l'extraction des alpha galactosides sur sa valeur nutritive. Etude sur le rat en croissance. Ann. Biol. anim. Bioch. Biophys., 18, 1393-1412.

VOHRA P., KATZER F. H., JOSLYN M. A., 1966. The growth depressing and toxic effects of tannins to chicks. Poultry Sci., 46, 132-142. 